\title{
Interaction of Hydrophobic Tungsten Cluster Complexes with a Phospholipid Bilayer
}

Ilya S. Dovydenko ${ }^{a}$, Yuliya A. Laricheva ${ }^{\mathrm{b}}$, Kseniya V. Korchagina ${ }^{\mathrm{a}}$, Alina E. Grigoryeva ${ }^{\mathrm{a}}$, Elena I. Ryabchikova ${ }^{\mathrm{a}, \mathrm{c}}$, Nikolay B. Kompankov, Denis P. Pishchur ${ }^{\mathrm{b}}$, Artem L. Gushchin ${ }^{\mathrm{b}, \mathrm{c}}$, Evgeny K. Apartsin ${ }^{\mathrm{a}, \mathrm{c}}$, Maxim N. Sokolov

a Institute of Chemical Biology and Fundamental Medicine SB RAS, 8, Lavrentiev ave., Novosibirsk, 630090, Russia;

${ }^{b}$ Nikolaev Institute of Inorganic Chemistry SB RAS, 3, Lavrentiev ave., Novosibirsk, 630090, Russia;

${ }^{c}$ Novosibirsk State University, 2 Pirogov str., Novosibirsk, 630090, Russia.

\section{Corresponding Authors}

* Dr. I. S. Dovydenko, E-mail: dovydenko_il@niboch.nsc.ru

\section{Study of the cluster stability upon embedding into lipid bilayers}

It is known that homoleptic $\left[\mathrm{M}_{3} \mathrm{~S}_{4} \mathrm{Cl}_{3}(\text { diimine })_{3}\right]^{+}$and their $\left.\left[\mathrm{M}_{3} \mathrm{~S}_{4} \mathrm{Cl}_{3} \text { (diphosphine }\right)_{3}\right]^{+}$ analogues $(\mathrm{M}=\mathrm{Mo}, \mathrm{W})$, as well as their cubane $\left\{\mathrm{M}_{3} \mathrm{M}^{\prime} \mathrm{S}_{4}\right\}$ derivatives can undergo ligand exchange reactions $\left[\mathrm{M}_{3} \mathrm{~S}_{4} \mathrm{X}_{3}(\mathrm{~L})_{3}\right]^{+}+3 \mathrm{Y}^{-} \rightarrow\left[\mathrm{M}_{3} \mathrm{~S}_{4} \mathrm{Y}_{3}(\mathrm{dmpe})_{3}\right]^{+}+3 \mathrm{X}^{-}(\mathrm{X}, \mathrm{Y}=\mathrm{H}$, halogenes, $\mathrm{SCN}, \mathrm{CF}_{3} \mathrm{COO}, \mathrm{BF}_{4}, \mathrm{OH}$ etc. $)^{1-8}$. Therefore, the substitution of $\mathrm{Cl}$ ligands with an O-donor acid residue, such as a phosphate, may occur. In view of this, the possibility of substitution in the cluster coordination sphere by a phospholipid was studied by ${ }^{1} \mathrm{H}$ and ${ }^{31} \mathrm{P}$ NMR spectroscopy. For this purpose, we compared the properties of PC and of mixture PC with the studied clusters $\left(\left[\mathrm{W}_{3} \mathrm{~S}_{4} \mathrm{Cl}_{3}(\mathrm{dbbpy})_{3}\right] \mathrm{Cl}\right.$ or $\left.\left[\mathrm{W}_{3} \mathrm{~S}_{4} \mathrm{Cl}_{3}(\mathrm{dnbpy})_{3}\right] \mathrm{Cl}\right)$. For this study we have chosen $5 \mathrm{~mol} \%$ of cluster content. Lipid compositions were prepared by thin films technique, and after were dissolved in $\mathrm{CDCl}_{3} / \mathrm{CD}_{3} \mathrm{OD}$ and analyzed by ${ }^{1} \mathrm{H}$ and ${ }^{31} \mathrm{P} \mathrm{NMR}$. According to the ${ }^{31} \mathrm{P} \mathrm{NMR}$ data (fig. S1), no changes of the chemical shifts were registered for both clusters.

The degradation of PC might proceed by four mechanisms: the cleavage of ester bonds in the $s n-1$ and $s n-2$ positions, the cleavage of the phosphoester bond in the $s n-3$ position, or the cleavage of the choline phosphoester. As ${ }^{31} \mathrm{P}$ NMR spectrum of PC no changed after the addition of clusters, to check stability of fatty acid esters of glycerol the same samples were analysed by ${ }^{1} \mathrm{H}$ NMR spectroscopy (fig. S2). ${ }^{1} \mathrm{H}$ NMR spectrum of the mixtures do not differ from the 
spectrum of PC alone (fig. S2). Thus, the cleavage of phosphatidylcholine does not occur when it is mixed with $\left[\mathrm{W}_{3} \mathrm{~S}_{4} \mathrm{Cl}_{3}(\mathrm{dbbpy})_{3}\right] \mathrm{Cl}$ or $\left[\mathrm{W}_{3} \mathrm{~S}_{4} \mathrm{Cl}_{3}(\mathrm{dnbpy})_{3}\right] \mathrm{Cl}$.
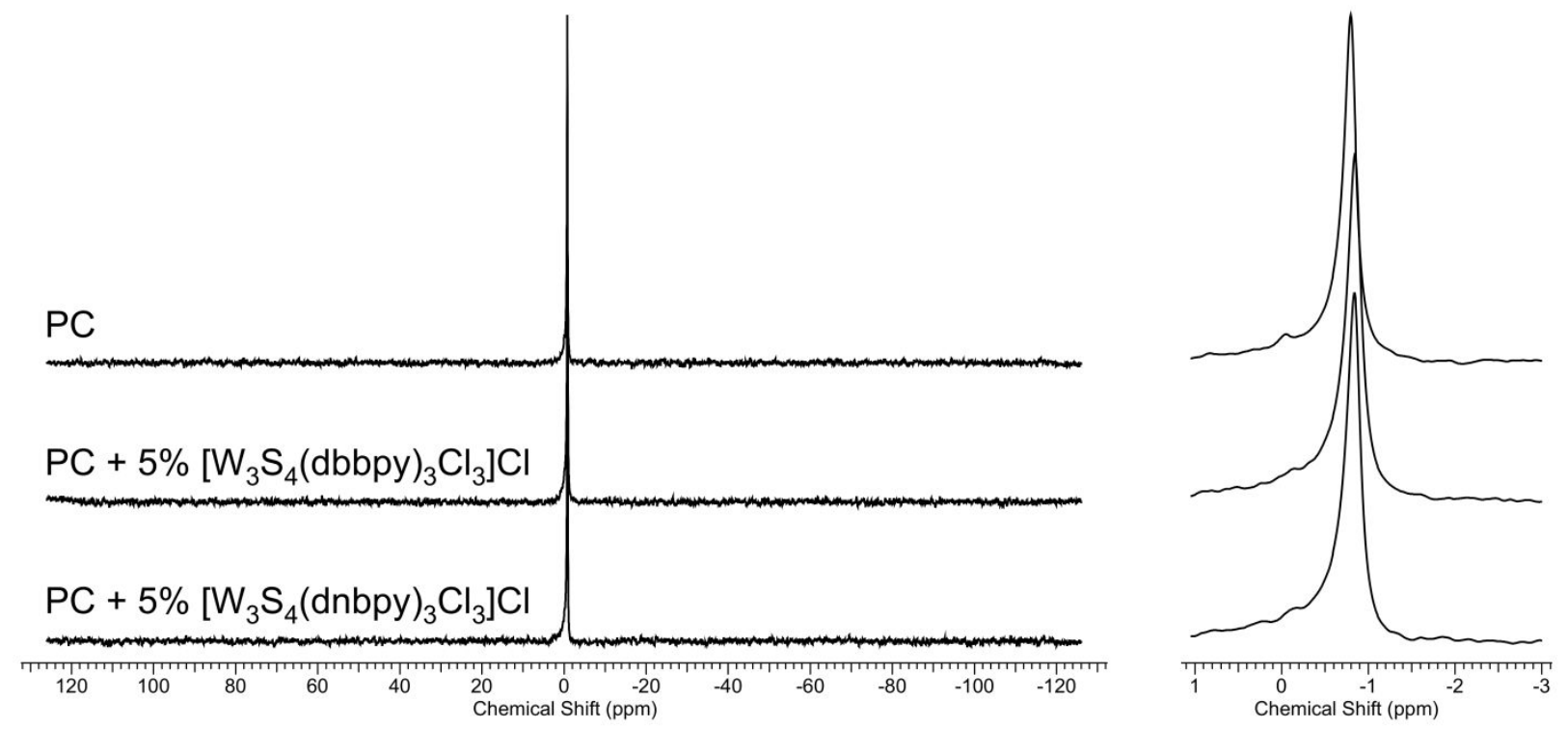

Fig. S1. ${ }^{31} \mathrm{P}$ NMR spectra of $1 \mathrm{mM}$ egg phosphatidylcholine (PC) in $\mathrm{CDCl}_{3} / \mathrm{CD}_{3} \mathrm{OD}$ and its mixture with $5 \mathrm{~mol} \%$ of $\left[\mathrm{W}_{3} \mathrm{~S}_{4} \mathrm{Cl}_{3}(\mathrm{dbbpy})_{3}\right] \mathrm{Cl}\left(\mathrm{PC}+\left[\mathrm{W}_{3} \mathrm{~S}_{4} \mathrm{Cl}_{3}(\mathrm{dbbpy})_{3}\right] \mathrm{Cl}\right)$ in $\mathrm{CDCl}_{3} / \mathrm{CD}_{3} \mathrm{OD}$, and with $5 \mathrm{~mol} \%$ of $\left[\mathrm{W}_{3} \mathrm{~S}_{4} \mathrm{Cl}_{3}(\mathrm{dnbpy})_{3}\right] \mathrm{Cl}\left(\mathrm{PC}+\left[\mathrm{W}_{3} \mathrm{~S}_{4} \mathrm{Cl}_{3}(\mathrm{dnbpy})_{3}\right] \mathrm{Cl}\right)$ in $\mathrm{CDCl}_{3} / \mathrm{CD}_{3} \mathrm{OD}$.
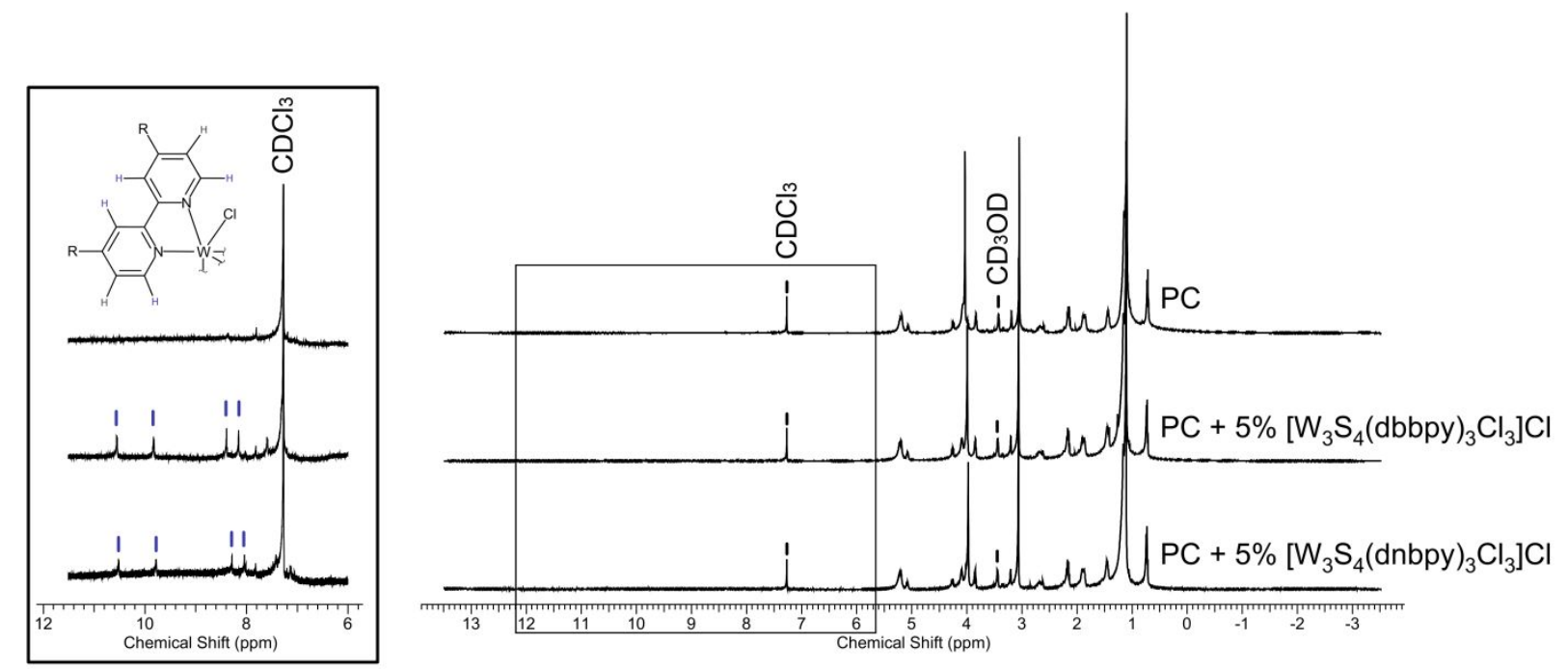

Fig. S2. ${ }^{1} \mathrm{H}$ NMR spectra: $1 \mathrm{mM}$ egg phosphatidylcholine in $\mathrm{CDCl}_{3} / \mathrm{CD}_{3} \mathrm{OD}$ (PC); mixture of 1 $\mathrm{mM}$ egg phosphatidylcholine with $5 \mathrm{~mol} \%$ of $\left[\mathrm{W}_{3} \mathrm{~S}_{4} \mathrm{Cl}_{3}(\mathrm{dbbpy})_{3}\right] \mathrm{Cl}$ in $\mathrm{CDCl}_{3} / \mathrm{CD}_{3} \mathrm{OD}(\mathrm{PC}+$ $\left.\left[\mathrm{W}_{3} \mathrm{~S}_{4} \mathrm{Cl}_{3}(\mathrm{dbbpy})_{3}\right] \mathrm{Cl}\right)$; mixture of $1 \mathrm{mM}$ egg phosphatidylcholine with $5 \mathrm{~mol} \%$ of $\left[\mathrm{W}_{3} \mathrm{~S}_{4} \mathrm{Cl}_{3}(\mathrm{dnbpy})_{3}\right] \mathrm{Cl}$ in $\mathrm{CDCl}_{3} / \mathrm{CD}_{3} \mathrm{OD}\left(\mathrm{PC}+\left[\mathrm{W}_{3} \mathrm{~S}_{4} \mathrm{Cl}_{3}(\mathrm{dnbpy})_{3}\right] \mathrm{Cl}\right)$. In the frame are enlarged part of spectra corresponding to chemical shifts from cluster ligands.

To check the integrity of cluster in condition of thin lipid film preparation PC/cluster mixtures were analyzed by ESI-MS. For this purpose, mixture of PC/cluster (1:1) were prepared by thin films technique, and after were dissolved in $\mathrm{CHCl}_{3}$ and analyzed. In the mass spectra 
(fig. S3,4), there are only two signals corresponding to the cluster compounds for both mixtures. Major signal corresponds to cluster cation (m/z: $1589.2-\left[\mathrm{W}_{3} \mathrm{~S}_{4} \mathrm{Cl}_{3}(\mathrm{dbbpy})_{3}\right]^{+} ; 2011.7-$ $\left.\left[\mathrm{W}_{3} \mathrm{~S}_{4} \mathrm{Cl}_{3}(\mathrm{dnbpy})_{3}\right]^{+}\right)$and minor signal belongs to product of cluster hydrolysis $(\mathrm{m} / \mathrm{z}: 1571.2$ $\left.\left[\mathrm{W}_{3} \mathrm{~S}_{4}(\mathrm{dbbpy})_{3} \mathrm{Cl}_{2} \mathrm{OH}\right]^{+} ; 1991.7-\left[\mathrm{W}_{3} \mathrm{~S}_{4}(\mathrm{dnbpy}){ }_{3} \mathrm{Cl}_{2} \mathrm{OH}\right]^{+}\right)$.

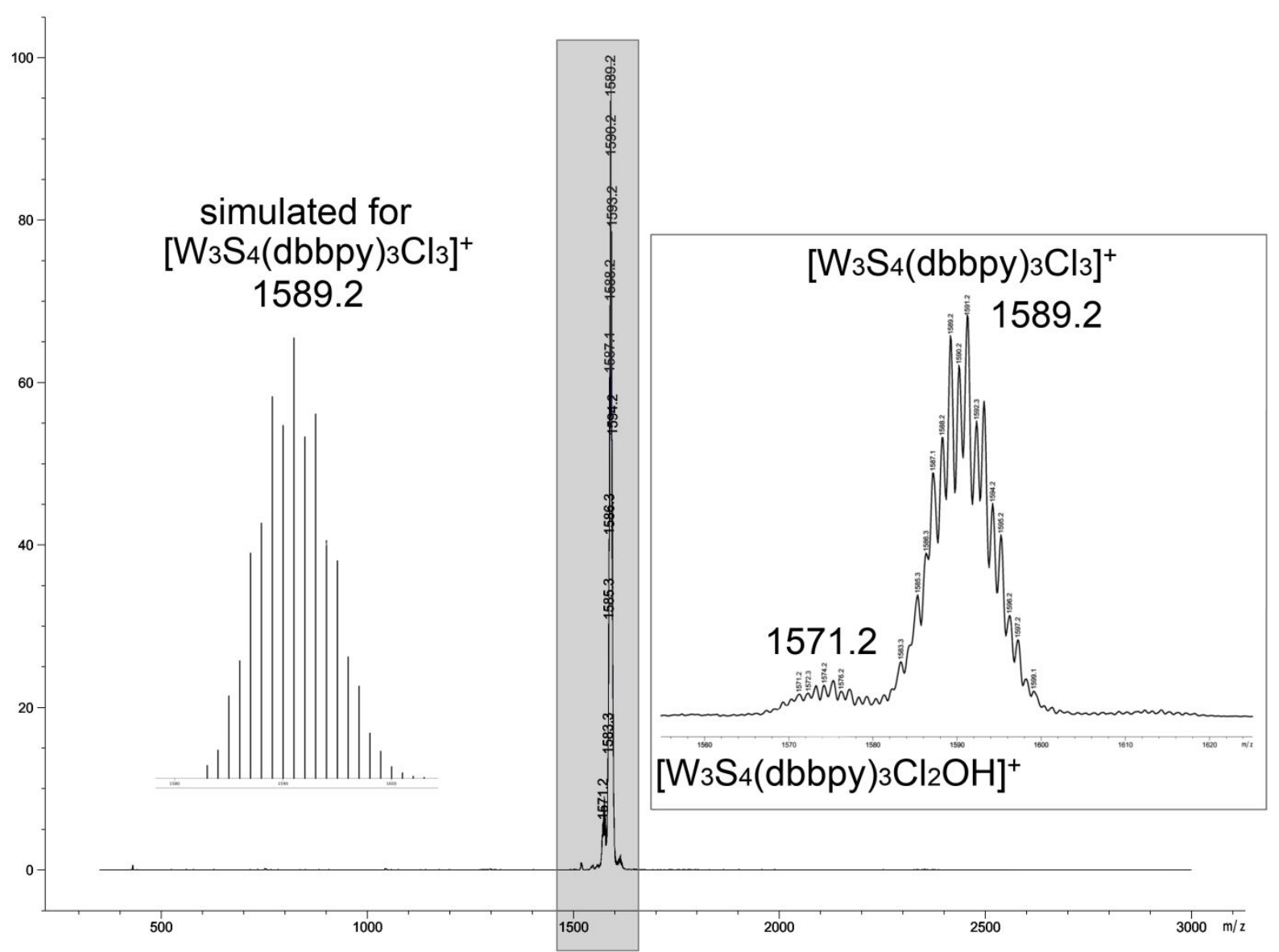

Fig. S3. ESI mass spectrum of mixture of $1 \mathrm{mM}$ egg phosphatidylcholine with $1 \mathrm{mM}$ $\left[\mathrm{W}_{3} \mathrm{~S}_{4} \mathrm{Cl}_{3}(\mathrm{dbbpy})_{3}\right] \mathrm{Cl}$ in $\mathrm{CHCl}_{3}$. 


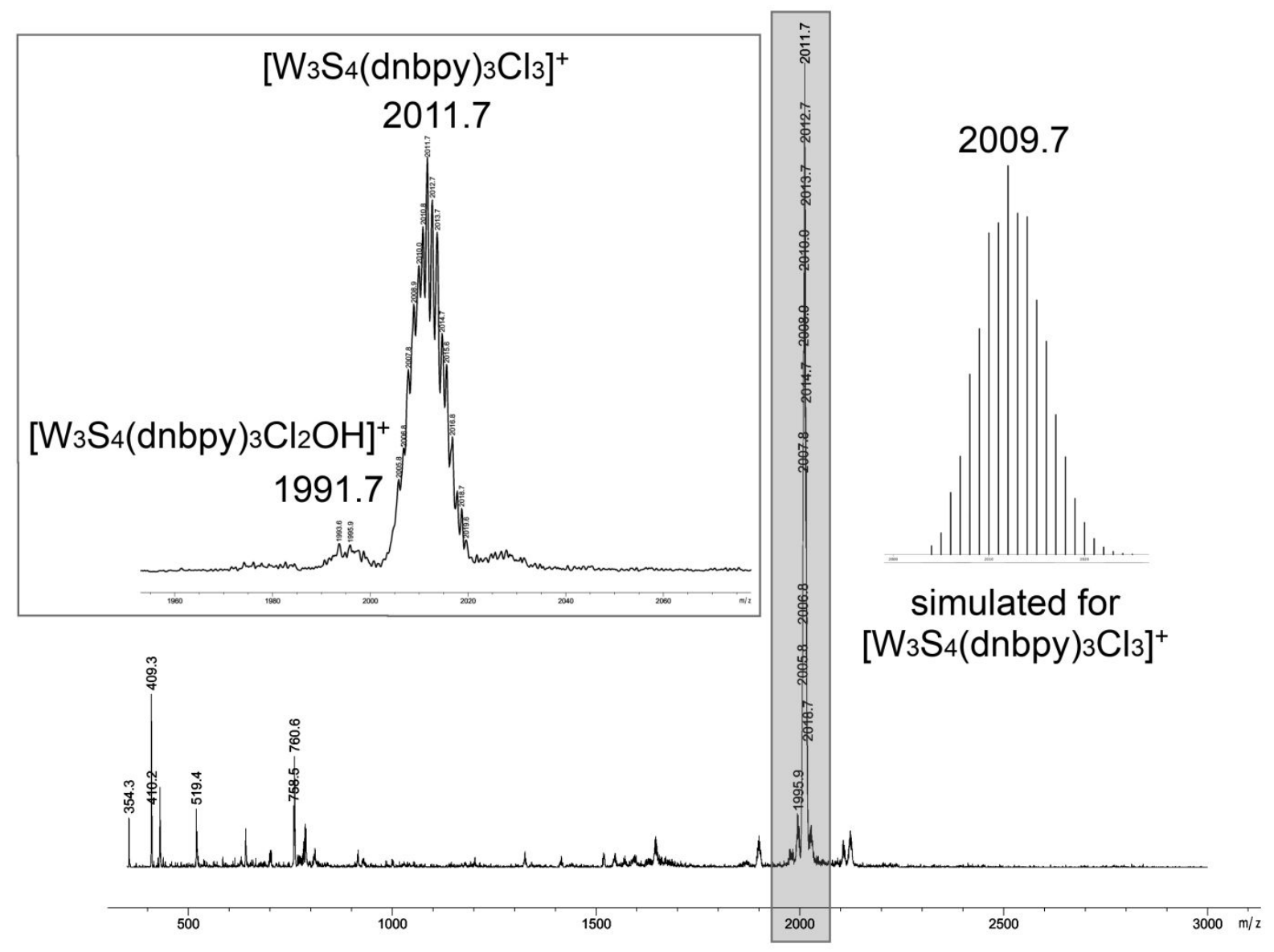

Fig. S4. ESI mass spectrum of mixture of $1 \mathrm{mM}$ egg phosphatidylcholine with $1 \mathrm{mM}$ $\left[\mathrm{W}_{3} \mathrm{~S}_{4} \mathrm{Cl}_{3}(\mathrm{dnbpy})_{3}\right] \mathrm{Cl}$ in $\mathrm{CHCl}_{3}$.

This pattern disproves the changes in the cluster's coordination sphere. In summary, we did not observe any interaction between positively charged cluster and PC phosphate. These data allow us to conclude that cluster compounds, even bearing potentially labile ligands, can be used for preparation of lipid-inorganic nanoconstructions, with no chemical reactions occurring between cluster and phospholipid. 

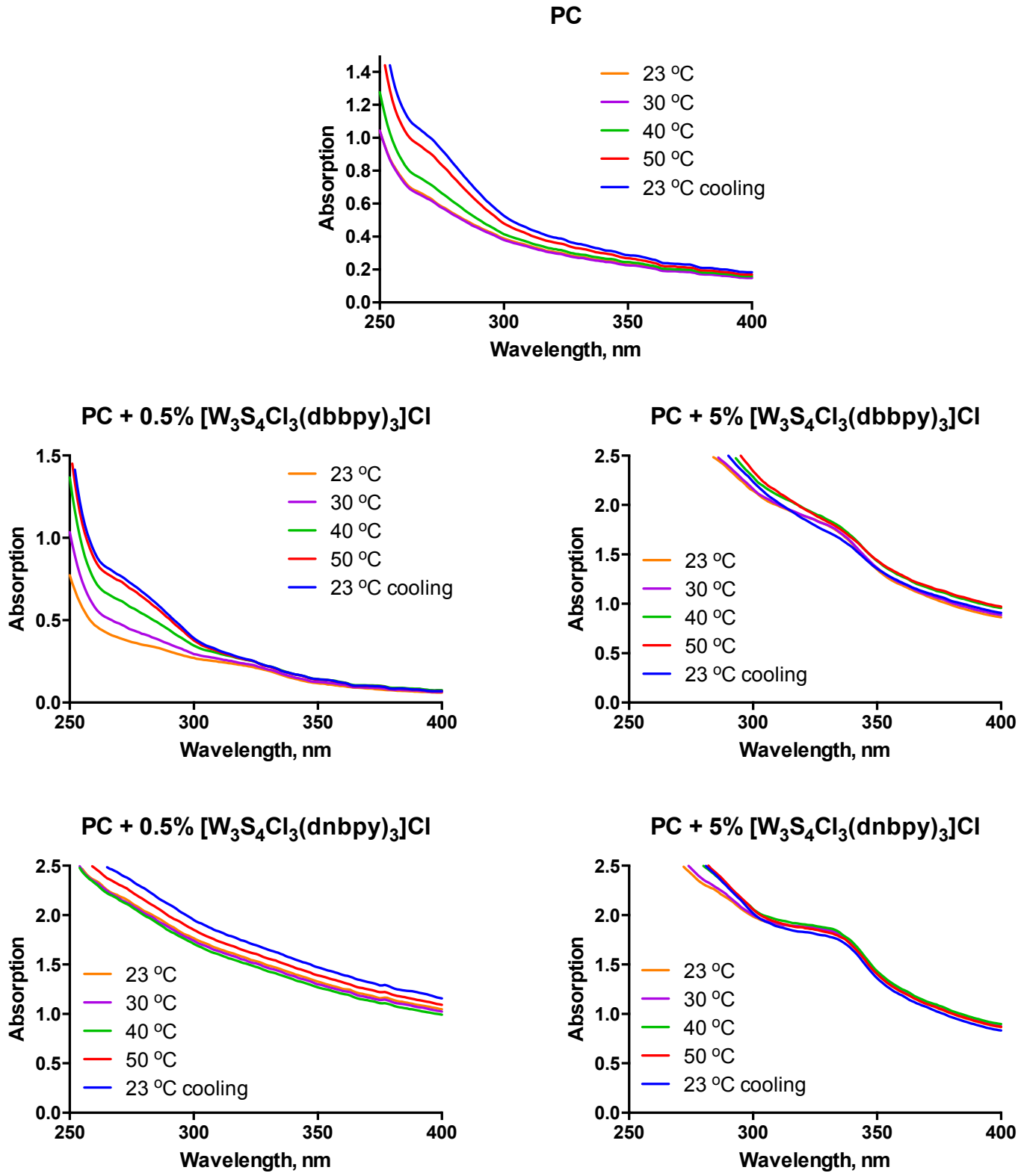

Fig. S5. UV-vis spectra of PC liposomes doped with the cluster complexes 


\section{Dynamic light scattering profiles of PC liposomes doped with the cluster complexes}

According to the DLS measurements, embedding of a cluster complex having di-tertbutyl-bipyridine ligands generally leads to the formation of smaller liposomes in comparison with a control, whereas the complex with di-nonyl-bipyridine ligands drives the liposome formation towards large particles. These data suggest that the nature of a hydrophobic moiety in the ligand plays a key role in the interaction with a lipid bilayer. In particular, it defines the effect of a cluster on the liposome morphology: rigid and spacious tert-butyl moieties are supposed to increase the bilayer curvature, whereas more flexible nonyl moieties would decrease it. However, the opposite occurs, for tert-butyl moieties have smaller molecular volume. Unlike the control liposomes, the heating of cluster-doped liposomes increases the number of large particles in the samples; after cooling back, the size distribution does not return to the initial one. Certain differences of the results obtained by DLS, NMR and TEM are explained by the polydispersity of the liposomes as well as different conditions of sample preparation and heating.

PC

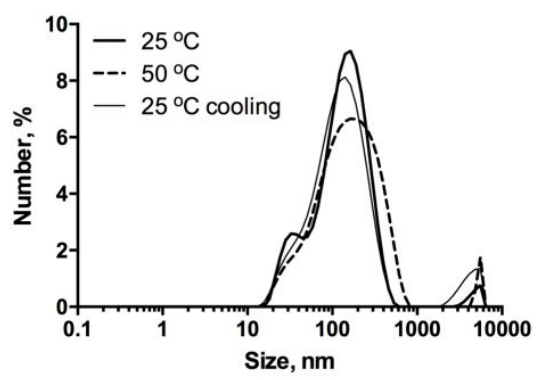

$\mathrm{PC}+0.5 \%\left[\mathrm{~W}_{3} \mathrm{~S}_{4} \mathrm{Cl}_{3}(\mathrm{dbbpy})_{3}\right] \mathrm{Cl}$

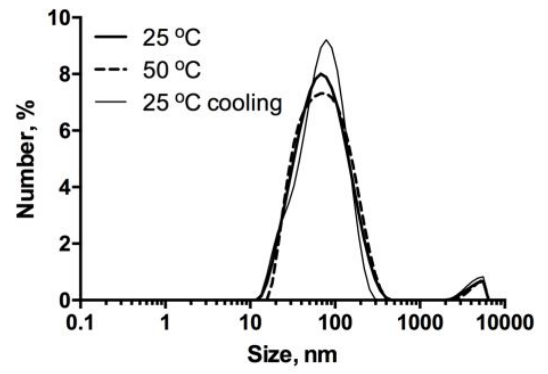

$\mathrm{PC}+5 \%\left[\mathrm{~W}_{3} \mathrm{~S}_{4} \mathrm{Cl}_{3}(\mathrm{dbbpy})_{3}\right] \mathrm{Cl}$

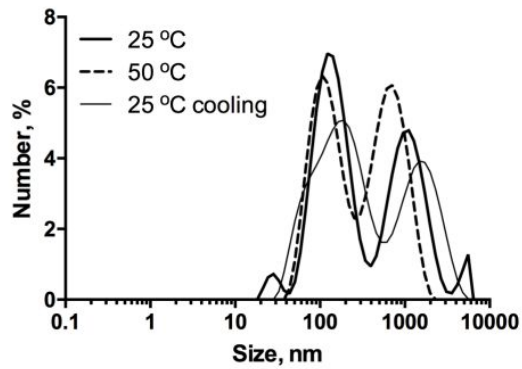

$\mathrm{PC}+0.5 \%\left[\mathrm{~W}_{3} \mathrm{~S}_{4} \mathrm{Cl}_{3}(\mathrm{dnbpy})_{3}\right] \mathrm{C}$

$\mathrm{PC}+5 \%\left[\mathrm{~W}_{3} \mathrm{~S}_{4} \mathrm{Cl}_{3}(\mathrm{dnbpy})_{3}\right] \mathrm{Cl}$
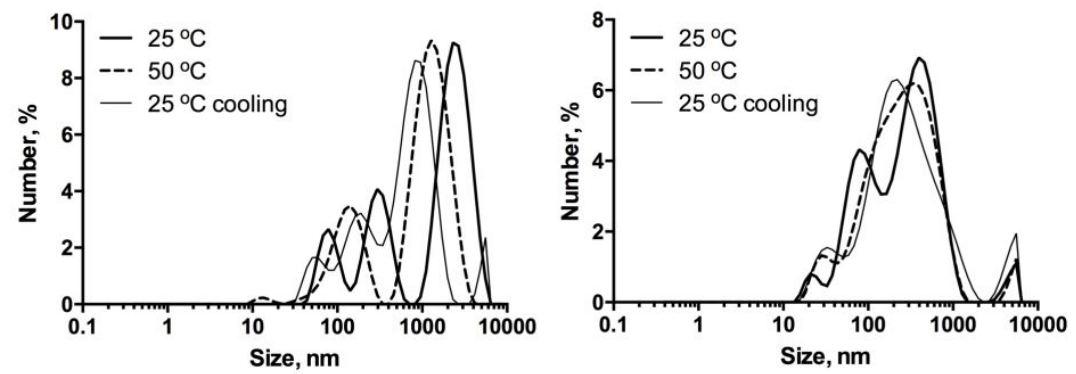

Fig. S6. DLS profiles of PC liposomes doped with the cluster complexes. Samples were incubated at $25{ }^{\circ} \mathrm{C}$, heated up to $50{ }^{\circ} \mathrm{C}$ and then cooled back to $25{ }^{\circ} \mathrm{C}$. 


\section{Transmission electron microscopy images}
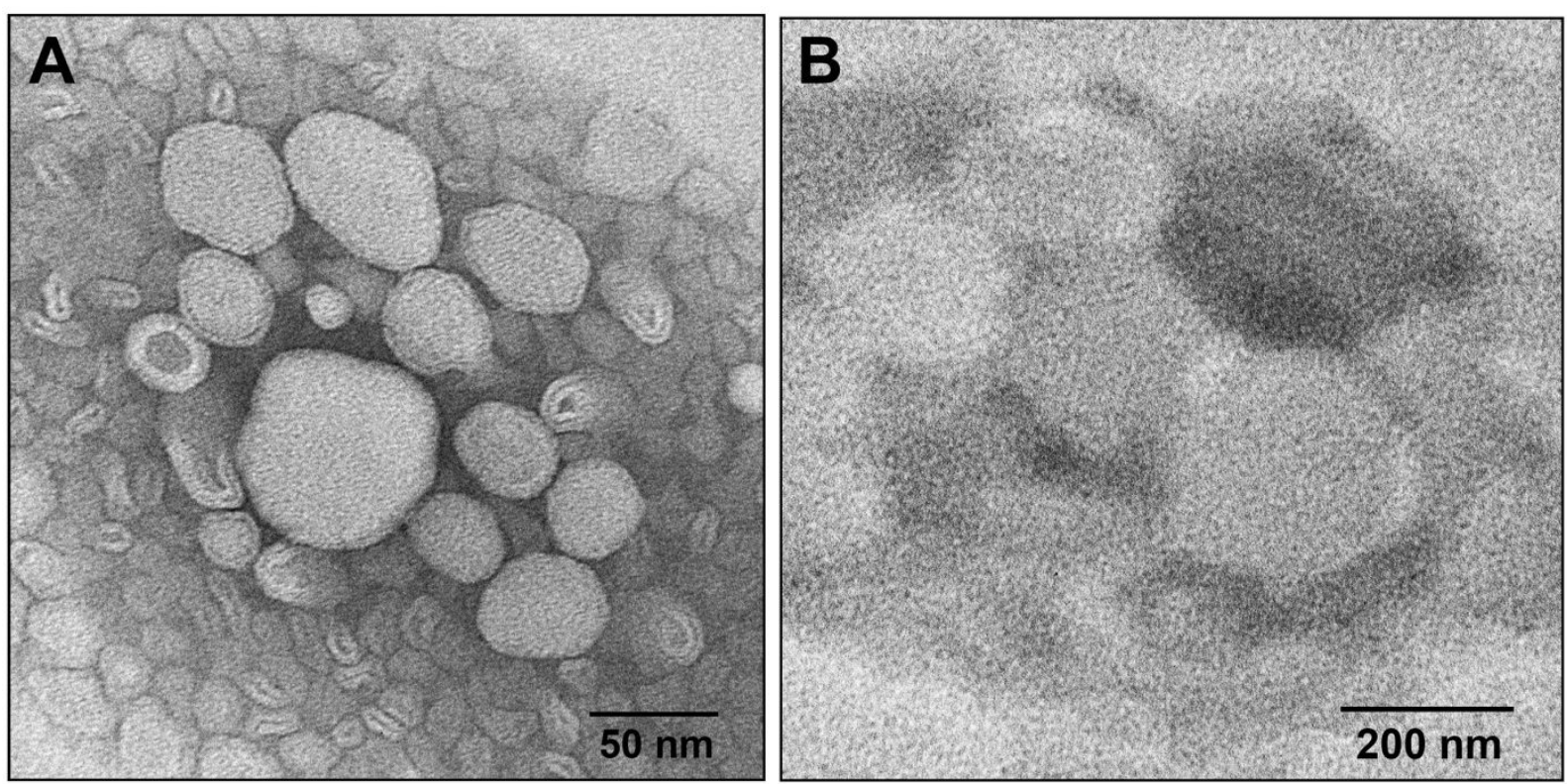

Fig. S7. TEM images of PC particles: A) with $0.1 \%$ ammonium orthomolybdate contrasting; B) without additional contrast.

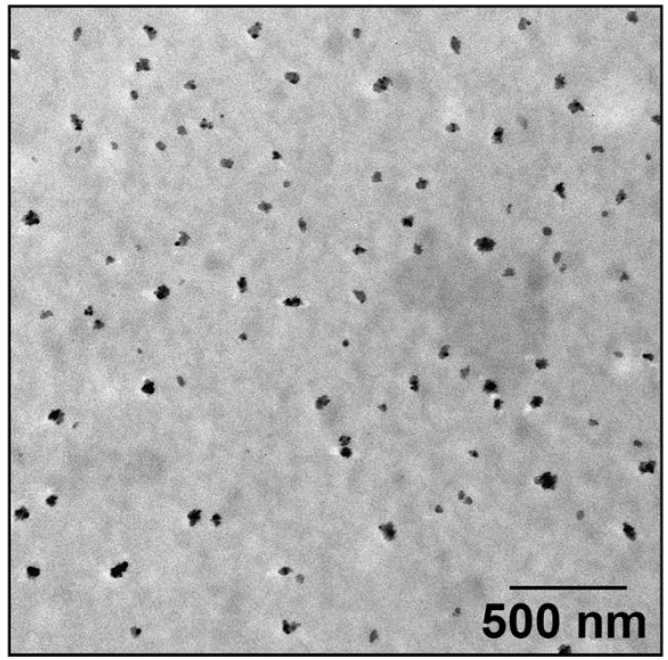

Fig. S8. TEM images of lipid nanoparticles doped with $0.5 \mathrm{~mol} \%$ of $\left[\mathrm{W}_{3} \mathrm{~S}_{4} \mathrm{Cl}_{3}(\mathrm{dbbpy})_{3}\right] \mathrm{Cl}$ after 20 min ultrasound irradiation. TEM, without additional contrast. 

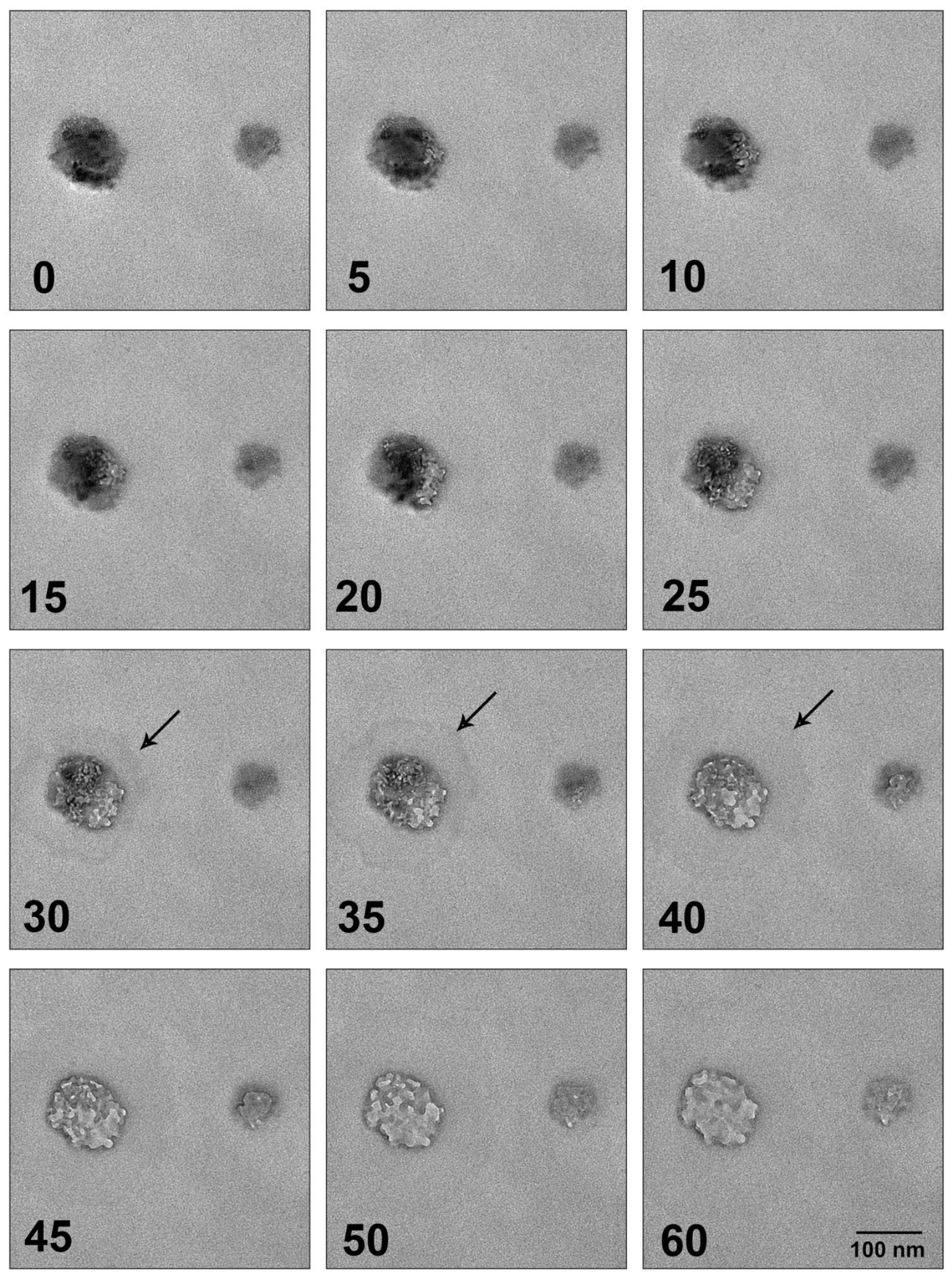

Fig. S9. Time-lapse filming of melting lipid nanoparticles doped with $0.5 \mathrm{~mol} \%$ of $\left[\mathrm{W}_{3} \mathrm{~S}_{4} \mathrm{Cl}_{3}(\mathrm{dbbpy})_{3}\right] \mathrm{Cl}$. TEM, without additional contrast. 


\section{References}

[1] A.L. Gushchin, R. Hernandez-Molina, A. V. Anyushin, M.R. Gallyamov, J. GonzalezPlatas, N.K. Moroz, M.N. Sokolov, Synthesis, structure and NMR studies of trinuclear Mo 3 S 4 clusters coordinated with dithiophosphate and chiral carboxylate ligands, New J. Chem. 40 (2016) 7612-7619. doi:10.1039/C6NJ01303A.

[2] J.Á. Pino-Chamorro, Y.A. Laricheva, E. Guillamón, M.J. Fernández-Trujillo, A.G. Algarra, A.L. Gushchin, P.A. Abramov, E. Bustelo, R. Llusar, M.N. Sokolov, M.G. Basallote, Kinetics Aspects of the Reversible Assembly of Copper in Heterometallic Mo $3 \mathrm{CuS} 4$ Clusters with 4,4'-Di- tert -butyl-2,2'-bipyridine, Inorg. Chem. 55 (2016) 9912-9922. doi:10.1021/acs.inorgchem.6b01878.

[3] T.F. Beltrán, J.Á. Pino-Chamorro, M.J. Fernández-Trujillo, V.S. Safont, M.G. Basallote, R. Llusar, Synthesis and Structure of Trinuclear W 3 S 4 Clusters Bearing Aminophosphine Ligands and Their Reactivity toward Halides and Pseudohalides, Inorg. Chem. 54 (2015) $607-$ 618. doi:10.1021/ic5025313.

[4] T.F. Beltrán, R. Llusar, M. Sokolov, M.G. Basallote, M.J. Fernández-Trujillo, J.Á. PinoChamorro, Influence of the Ligand Alkyl Chain Length on the Solubility, Aqueous Speciation, and Kinetics of Substitution Reactions of Water-Soluble M 3 S 4 (M= Mo, W) Clusters Bearing Hydroxyalkyl Diphosphines, Inorg. Chem. 52 (2013) 8713-8722. doi:10.1021/ic400897y.

[5] M.G. Basallote, M.J. Fernández-Trujillo, J.Á. Pino-Chamorro, T.F. Beltrán, C. Corao, R. Llusar, M. Sokolov, C. Vicent, Water-Soluble Mo 3 S 4 Clusters Bearing Hydroxypropyl Diphosphine Ligands: Synthesis, Crystal Structure, Aqueous Speciation, and Kinetics of Substitution Reactions, Inorg. Chem. 51 (2012) 6794-6802. doi:10.1021/ic300517g.

[6] A.G. Algarra, M.G. Basallote, M.J. Fernández-Trujillo, E. Guillamón, R. Llusar, M.D. Segarra, C. Vicent, Synthesis, Crystal Structure, Aqueous Speciation, and Kinetics of Substitution Reactions in a Water-Soluble Mo 3 S 4 Cluster Bearing Hydroxymethyl Diphosphine Ligands, Inorg. Chem. 46 (2007) 7668-7677. doi:10.1021/ic701082p.

[7] A.G. Algarra, M.G. Basallote, M. Feliz, M.J. Fernández-Trujillo, R. Llusar, V.S. Safont, The Role of Solvent on the Mechanism of Proton Transfer to Hydride Complexes: The Case of the [W 3 PdS 4 H 3 (dmpe) 3 (CO)] + Cubane Cluster, Chem. Eur. J. 16 (2010) 1613-1623. doi:10.1002/chem.200902233.

[8] A.G. Algarra, M.G. Basallote, M. Feliz, M.J. Fernández-Trujillo, R. Llusar, V.S. Safont, New Insights into the Mechanism of Proton Transfer to Hydride Complexes: Kinetic and Theoretical Evidence Showing the Existence of Competitive Pathways for Protonation of the Cluster [W3S4H3(dmpe)3]+ with Acids, Chem. Eur. J. 12 (2006) 1413-1426. doi:10.1002/chem.200500695. 
